\title{
Septicaemia in a granulocytopenic patient caused by Corynebacterium striatum
}

\author{
Lawrence Dall', William G. Barnes ${ }^{2}$ and Dennis Hurford ${ }^{1}$
}

\begin{abstract}
${ }^{1}$ Department of Medicine, University of Missouri, School of Medicine-Kansas City, 2411 Holmes Street, Kansas City, Missouri 64108 and $^{2}$ Department of Pathology, Truman Medical Center, and School of Medicine, University of Missouri-Kansas City, 2301 Holmes Street, Kansas City, Missouri 64108, USA.
\end{abstract}

\begin{abstract}
Summary: A 64 year old woman with metastatic endometrial carcinoma was admitted to the hospital after three grand mal seizures. Blood cultures yielded Corynebacterium striatum. The patient responded to parenteral ampicillin therapy. This is believed to be the first case of sepsis caused by this organism.
\end{abstract}

\section{Introduction}

Neutropenic patients are susceptible to a wide variety of infections from unusual organisms. The incidence of bacteraemia increases as the neutrophil count falls below $500 \times 10^{6} / 1$ with most of the organisms originating from the patient's endogenous flora. The organism implicated in this case, Corynebacterium striatum, is recognized as a part of the microbial flora of the human skin and nasal mucous membranes.

We believe this report to be the first documented case of sepsis caused by $C$. striatum.

\section{Case report}

A 64 year old woman was admitted to the hospital after three grand mal seizures. She was known to have metastatic endometrial carcinoma diagnosed initially in 1985 , treated with radiation therapy in 1985. Four months prior to admission, metastatic lesions were noted in lymph nodes, lung and brain. A Hickman catheter was inserted by the subclavian route and chemotherapy was begun with cis-platinum, cyclophosphamide, and doxorubicin. She received her last dose of chemotherapy 11 days before admission. The patient was diabetic and hypertensive requiring chronic insulin and diuretic therapy. Physical examination revealed a patient in no acute distress with a temperature of $102.3^{\circ} \mathrm{F}$, blood pressure of $110 / 60 \mathrm{mmHg}$ and pulse $100 /$ minute. Her neck was supple, examination of the lungs revealed decreased breath sounds bilaterally, abdominal examination revealed a $16 \mathrm{~cm}$ hard nodular liver, and rectal examination was positive for occult blood. Initial laboratory results included: haemoglobin $7.8 \mathrm{~g} / \mathrm{dl}$,

Correspondence: Lawrence Dall, M.D.

Accepted: 28 November 1988 platelet count $95 \times 10^{9} / 1$, and white blood cell count $0.99 \times 10^{9} / 1$ (48\% polymorphonuclear leucocytes). Chest X-ray, and cranial computed tomography revealed multiple metastatic lesions. Two sets of blood cultures ( $4 / 4$ bottles) obtained on admission revealed a nonsporulating, aerobic, weakly haemolytic, nonmotile, catalase positive, pleomorphic diptheroid-like, Gram-positive bacillus which fermented glucose, fructose, mannose, lactose and maltose. The identification of the isolate was confirmed by the Missouri State Laboratory as Corynebacterium striatum. Minimal antibiotic inhibitory concentrations of the isolate included: ampicillin $<0.25 \mu \mathrm{g} / \mathrm{ml}$, cephalothin $<4 \mu \mathrm{g} / \mathrm{ml}$, chloramphenicol $<2 \mu \mathrm{g} / \mathrm{ml}$, clindamycin $<0.5 \mu \mathrm{g} / \mathrm{ml}$, erythromycin $<0.5 \mu \mathrm{g} / \mathrm{ml}$, gentamicin $<1 \mu \mathrm{g} / \mathrm{ml}$, oxacillin $0.5 \mu \mathrm{g} / \mathrm{ml}$, penicillin $0.6 \mu \mathrm{g} / \mathrm{ml}$, and vancomycin $<2 \mu \mathrm{g} / \mathrm{ml}$.

Therapy was initiated with ampicillin 1 gram intravenously every 4 hours and gentamicin $120 \mathrm{mg}$ every 8 hours, on the first day of hospitalization. Four days after antibiotics were started, the patient became afebrile, white blood cell count rose to $2.3 \times 10^{9} / 1$ and repeat blood cultures were sterile. Parenteral therapy was discontinued after 7 days and she was continued on ampicillin $500 \mathrm{mg}$ orally every 6 hours for 7 additional days.

\section{Discussion}

Corynebacterium species, other than diphtheriae, that have caused bacteraemia include $C$. xerosis, ${ }^{1,2} C$. pseudodiphthericum, ${ }^{3}$ C. equi, ${ }^{4}$ C. bovis, ${ }^{5,6}$ C. haemolyticum ${ }^{7}$ C. aquaticum, ${ }^{8}$ C. (Actinomyces) pyogenes, ${ }^{9,10}$ $C$. group $\mathrm{JK},{ }^{4,7,11}$ and $C$. group $\mathrm{G}-2^{12}$. This organism was first isolated from human nasal mucosa and named Bacterium striatum by Chester ${ }^{13}$; however, 
Holland ${ }^{14}$, classified the organism later as $C$. flavidum. $C$. striatum has only been reported twice as a human pathogen, once as a cause of pleuropulmonary infection in a patient with chronic lymphocytic leukaemia ${ }^{15}$ and once from a patient with a pulmonary abscess and empyema. ${ }^{16}$

Species of Corynebacterium (diptheroids) are nor-

\section{References}

1. Geraci, J., Forth, R. \& Ellis, F.H. Postoperative prosthetic valve bacterial endocarditis due to Corynebacterium xerosis. Mayo Clin Proc 1967, 42: 736-743.

2. Porschen, P.K., Goodman, Z. \& Rafai, B. Isolation of Corynebacterium xerosis from clinical specimens. Am J Clin Pathol 1977, 68: 290-293.

3. Tow, A. \& Wechsler, H.F. Diptheroid bacillus as a cause of acute endocarditis. Am J Dis Child 1932, 44: 156-162.

4. Hollis, D.G. \& Weaver, R.E. Gram-positive Organisms: $A$ guide to Identification. Special Bacteriology Section, Center for Disease Control, Atlanta, Ga., 1979, p. 6.

5. Bolton, W.K. \& Sande, M.A. Ventriculojugular shunt nephritis with Corynebacterium bovis - successful therapy with antibiotics. Am J Med 1975, 59: 417-423.

6. Vale, J.A. \& Scott, G.W. Corynebacterium bovis as a cause of human disease. Lancet 1977, ii: 682-684.

7. Jobanputura, R.S. \& Swain, C.P. Septicemia due to Corynebacterium haemolyticum. J Clin Pathol 1975, 28: 798-800.

8. Weiner, M. \& Werthamer, S. Corynebacterium aquaticum septicemia: characterization of the microorganism Am J Clin Pathol 1975, 64: 378-381.

9. Ballard, D.O., Upsher, A.E. \& Seeley, D.D. Infection with Corynebacterium pyogenes in man. Am J Clin Pathol 1947, 17: 209-215. mally present on the skin and mucous membranes in large numbers. While usually considered a contaminant in the normal host, identification of the organisms in the neutropenic patient often represents severe infection. We describe in a granulocytopenic patient the first reported case of Corynebacterium striatum septicaemia.

10. Jootar, P., Sherunpong, V. \& Sartana, K. Corynebacterium pyogenes endocarditis: report of a case with necropsy and review of the literature. $J$ Med Assoc Thai 1978, 61: 596-599.

11. Johnson, W., Cobb, Ardite, L. \& Kaye, D. Diptheroid endocarditis after insertion of a prosthetic heart valve. JAMA 1968, 203: 919-921.

12. Austin, G.E. \& Hill, E.O. Endocarditis due to Corynebacterium groups G-2. J Infect Dis 1983, 147: 1106.

13. Chester, F.D. A Manual of Determinative Bacteriology. The Macmillan Co., New York, 1901, p. 8.

14. Holland, D.F. In: Winslow, C.E.A., Broadhurst, J., Buchanan, R.E., Krumwiede, C., Rogers, L.A. \& Smith, G.H. (eds) The Families and Genera of the Bacteria. Final report of the committee of the Society of American Bacteriologists on the characterization and classification of bacterial types. J Bacteriol 1920, 5: 191-222.

15. Bowstead, T.T. \& Santiago, S.M. Pleuropulmonary infection due to Corynebacterium striatum. $\mathrm{Br} J \mathrm{D} / \mathrm{S}$ Chest 1980, 74: 198-200.

16. Barr, J. \& Murphy, P.J. Corynebacterium striatum: A unusual organism isolated in pure culture from sputum. Infect 1986, 13: 297-298. 